\title{
LIETUVOS OLIMPINĖS SLIDINĖJIMO RINKTINĖS KANDIDATU TRENIRUOTĖS KRŪVIAI, FIZINIO DARBINGUMO, FUNKCINIUU GALIŲ IR PSICHOEMOCINĖS BŪSENOS KAITA PER TREČIUS OLIMPINIO CIKLO METUS
}

\author{
Algirdas Čepulėnas, Arvydas Stasiulis, Jonas Poderys \\ Lietuvos kūno kultūros akademija, Kaunas, Lietuva
}

\begin{abstract}
Algirdas Čepulẻnas. Socialinių mokslų (edukologijos) habilituotas daktaras. Sporto technologijų katedros vedèjas, e. profesoriaus pareigas. Moksliniu tyrimų kryptis - sportininkų rengimo valdymo modeliavimas.
\end{abstract}

\begin{abstract}
SANTRAUKA
Treniruotès vyksmo kryptingumas ir jo valdymas atsižvelgiant i slidininku organizmo adaptacijos prie fiziniu krūviu individualius ypatumus - labai svarbūs veiksniai, lemiantys sportinio rengimo efektyvuma.

Tyrimo tikslas - išnagrinèti Lietuvos slidinejimo olimpinès rinktinès kandidatu fizinius krūvius, nustatyti fizinio darbingumo, funkciniu galiu, psichoemocinès būsenos kaitos ypatumus trečiais olimpinio ciklo metais. Tyrimo objektas - slidininku lenktynininku, besirengiančiu dalyvauti 2006 m. Turino olimpinèse žiemos žaidynèse, treniruotès krūviai, fizinio darbingumo, koju raumenu galingumo, duju apykaitos, kvépavimo, širdies susitraukimu dažnio, psichoemocinès büsenos, vestibulinès funkcijos rodikliai ir ju kaita per 2004-2005 metu rengimo cikla.

Slidininkai tris kartus buvo tiriami Lietuvos kūno kultūros akademijos (LKKA) Žmogaus motorikos ir Kineziologijos laboratorijose.

Atliekant nenutrūkstama nuosekliai didinama fizinį krūvi veloergometru „,Monark“, duju analizatoriumi „, Oxycon Mobile" buvo registruojama: plaučiu ventiliacija, kvèpavimo dažnis, deguonies suvartojimas, deguonies pulsas, kvépavimo koeficientas, deguonies suvartojimas $1 \mathrm{~W}$ atliekamo darbo. Nustatytos aerobinio ir anaerobinio slenksčio ir kritinio intensyvumo ribos. Kineziologijos laboratorijoje ištirta koju raumenu susitraukimo galingumas ir ištvermé, vestibulinè funkcija ir psichoemocinè būsena.

Slidininku cikliniu pratimu (bègimo, slydimo büdu imitavimo, važiavimo riedslidèmis, slidinèjimo) krūvis per 20042005 metu treniruotès cikla sieké: slidininkès I. T. -7313,5 km, slidininku A. N. - $7138 \mathrm{~km}, \mathrm{M}$. S. $-6274 \mathrm{~km}$. Slidininku deguonies suvartojimo $\left(\mathrm{VO}_{2}\right)$ ir širdies susitraukimu dažnio ties anaerobinès apykaitos slenksčio riba reikšmès artimos šiu rodikliu reikšmèms, pasiekus kritinio intensyvumo riba, ir tai rodo dideli ju aerobiniu galiu talpumq. Deguonies suvartojimas procentais nuo $V_{2 \max }$ ties anaerobinio slenksčio riba atitinka didelio meistriškumo ištvermés sportininku modelinius rodiklius: I. T. $-89,49 \%$, A. N. $-81,1 \%$, M. S. $-84,0 \%$ VO $_{2 \max }$. Slidininku maksimaliojo deguonies suvartojimo rodikliai daug mažesni negu elito slidininku modeliniai rodikliai. Tikslinga per treniravimo vyksmq taikyti daugiau fiziniu krūviu, skatinančiu $V O_{2 \max }$ didejimq. Slidininku vestibulinès funkcijos rodikliai varžybu laikotarpio pabaigoje buvo geresni negu parengiamuoju laikotarpiu. Psichoemocinès būsenos rodikliu kaita reiškiasi individualiais požymiais.
\end{abstract}

Raktažodžiai: olimpinis ciklas, fizinis krūvis, fizinis darbingumas, funkcinis pajègumas, anaerobinis slenkstis, širdies susitraukimu dažnis.

\section{IVADAS}

$\mathrm{S}$ lidininkų lenktynininkų sportinius rezultatus lemia genetiniai gebèjimai, biologinis amžius, treniravimo stažas, judamieji gebējimai, treniravimo krūviai ir organizmo adaptacija prie sportinio rengimo krūviu (Eisenman et al., 1989; Hottenrott, Urban, 1998; Раменская, 2000; Hoff et al., 2002; Millet et al., 2003).

Keičiantis slidinèjimo lenktynių varžybų programoms, tobulëjant treniravimo metodologijai, atsigavimo priemonems ir metodams pasaulio čempionatuose ir olimpinèse žiemos žaidynèse, iškyla nauji uždaviniai gerinant didelio meistriškumo slidininku rengimą. Reikia vis geriau pažinti slidininko organizmo adaptacijos eiga ir jos ypatumus (Milašius, 1997; Osteras et al., 2002; Welde et al., 2003). Dél tobulesnio slidinejjimo inventoriaus, naujų slidžių tepimo ir slidinejjimo trasų rengimo technologijų labai padidèjo slidininkų varžybiniai greičiai įveikiant ivairius nuotolius ir sutrumpejo nuotolių įveikimo laikas. Šiuolaikinès slidinèjimo lenktynès reikalauja didelio aerobinio darbo galingumo, gebėjimo 
dirbti mišrioje aerobinèje-anaerobinèje energijos gamybos zonoje ir raumenu susitraukimu galingumo ištvermès (Komi, Norman, 1987; Paavolainen et al., 1991; Gaskill et al., 1999; Баталов, 2000; Раменская, 2000; Mahood et al., 2001; Osteras et al., 2002).

Slidininkams, dalyvaujantiems sprinto lenktynèse, labai svarbūs darbo galingumo ir darbo ištvermès rodikliai gaminant energiją anaerobiniu glikolitiniu būdu (Rusko, 2003 a). Treniravimo vyksmo modeliavimas ir valdymas atsižvelgiant i organizmo adaptacijos prie fizinių krūvių individualius ypatumus yra labai svarbūs veiksniai, lemiantys sportinio rengimo efektyvumą (Платонов, 1997; Bompa, 1999; Čepulènas, 2001; Raslanas, 2001; Верхошанский, 2005).

Darome prielaida, kad ištyrus ir gerai išanalizavus Lietuvos olimpinès slidinejjimo rinktinès kandidatų rengimo programa, fizinio darbingumo ir organizmo funkcinio pajègumo kaitą trečiais olimpinio ciklo metais galima sékmingai koreguoti slidininkų rengimą per ketvirtus (paskutinius) olimpinio ciklo metus.

Tyrimo tikslas - išnagrinèti Lietuvos slidinejjimo olimpinès rinktinès kandidatu fizinius krūvius, ištirti fizinio darbingumo, funkcinių galių ir psichoemocinès būsenos kaitos ypatumus trečiais olimpinio ciklo metais.

Tyrimo objektas - slidininkų, kandidatų dalyvauti $2006 \mathrm{~m}$. Turino olimpinèse žiemos žaidynèse, fiziniai krūviai, fizinio darbingumo, kojų raumenų susitraukimo galingumo, kvėpavimo bei dujų apykaitos, širdies susitraukimų dažnio, psichoemocinès būsenos, vestibulinès funkcijos rodikliai ir jų kaita.

\section{TYRIMO METODIKA IR ORGANIZAVIMAS}

Taikyti šie metodai: mokslo darbų studijos, slidininkų rengimo ir varžybų dokumentų, individualių treniruotès dienynų analizè, testavimas.

Trečiais olimpinio ciklo metais, per 20042005 metu rengimo ciklą, buvo tiriami Lietuvos olimpinès slidinèjimo lenktynių rinktinès kandidatai I. Terentjeva (I. T.), A. Novoselskis (A. N.), M. Strolia (M. S.), kurie rengiasi dalyvauti $2006 \mathrm{~m}$. XX olimpinèse žiemos žaidynèse Turine. Slidininkų amžius $2005 \mathrm{~m}$. varžybų laikotarpiu: I. T. -21 , A. N. -20 , M. S. -19 metu.

Slidininku išplèstinis tyrimas buvo atliktas tris kartus. Lietuvos kūno kultūros akademijos
Žmogaus motorikos laboratorijoje nustatyti fizinio darbingumo, kvėpavimo, dujų apykaitos, širdies susitraukimų dažnio rodikliai atliekant nenutrūkstamą nuosekliai didinamą fizinį krūvị veloergometru „Monark“. Mynimo dažnis 70 aps. / min. Darbo metu nešiojamuoju duju analizatoriumi „Oxycon Mobile“ (Vokietija) nenutrūkstamai buvo registruojama: plaučiu ventiliacija, kvejpavimo dažnis, deguonies suvartojimas (VO2), deguonies pulsas, kvèpavimo koeficientas, deguonies suvartojimas $1 \mathrm{~W}$ atliekamo darbo. Visų tyrimų metu širdies susitraukimų dažnis (ŠSD) registruojamas ir įrašinejjamas $\mathfrak{i}$ atminti pulso matuokliu „Polar AccuRex-Plus“. Fizinis krūvis buvo didinamas, kol pasiekiama kritinio intensyvumo riba. Nustatytos aerobinio ir anaerobinio slenksčio bei kritinio intensyvumo ribos ir darbo galingumo, deguonies suvartojimo, širdies susitraukimų dažnio, plaučių ventiliacijos rodikliai ties šiomis ribomis. Baigus fizini krūvi po 4 minučių buvo imamas kapiliarinis kraujo mèginys iš piršto ir nustatoma laktato koncentracija naudojant modifikuotą analizatoriu „Eksan-G“.

LKKA Kineziologijos laboratorijoje buvo nustatytas slidininkų kojų raumenų susitraukimo galingumas atliekant šuolius ant kontaktinès platformos su kompiuterine iranga pagal C. Bosco (1999) metodiką. Kojų raumenų ištvermei nustatyti slidininkai atliko $30 \mathrm{~s}$ šuoliavimo testą. Šuoliai buvo atliekami maksimaliomis pastangomis pasispiriant abiem kojom, rankas laikant ant liemens ir nusileidžiant ant žemès $90^{\circ} \mathrm{kam}-$ pu. Prieš $30 \mathrm{~s}$ šuoliu testą, baigus ji ir per dvi atsigavimo minutes buvo registruojamas širdies susitraukimų dažnis ir arterinis kraujospūdis. Vestibulinė funkcija tirta sukamaisiais mėginiais, o psichoemocinè būsena - naudojant miokinetini Mizo-Lopeso psichodiagnostikos testą (Jasiūnas ir kt., 1997). Visi rodikliai buvo registruojami ir vertinami specialiomis kompiuterinemis programomis, sukurtomis LKKA Kineziologijos laboratorijoje.

\section{REZULTATAI}

Slidininkų sportinis rengimas per 2004-2005 metų ciklą vyko pagal Lietuvos tautinio olimpinio komiteto Vykdomojo komiteto bei Kūno kultūros ir sporto departamento prie Lietuvos Respublikos Vyriausybès patvirtintą Lietuvos sportininku rengimo ir dalyvavimo XX žiemos olimpinese žaidynèse programa ,, Turinas 2006“"(2003). 


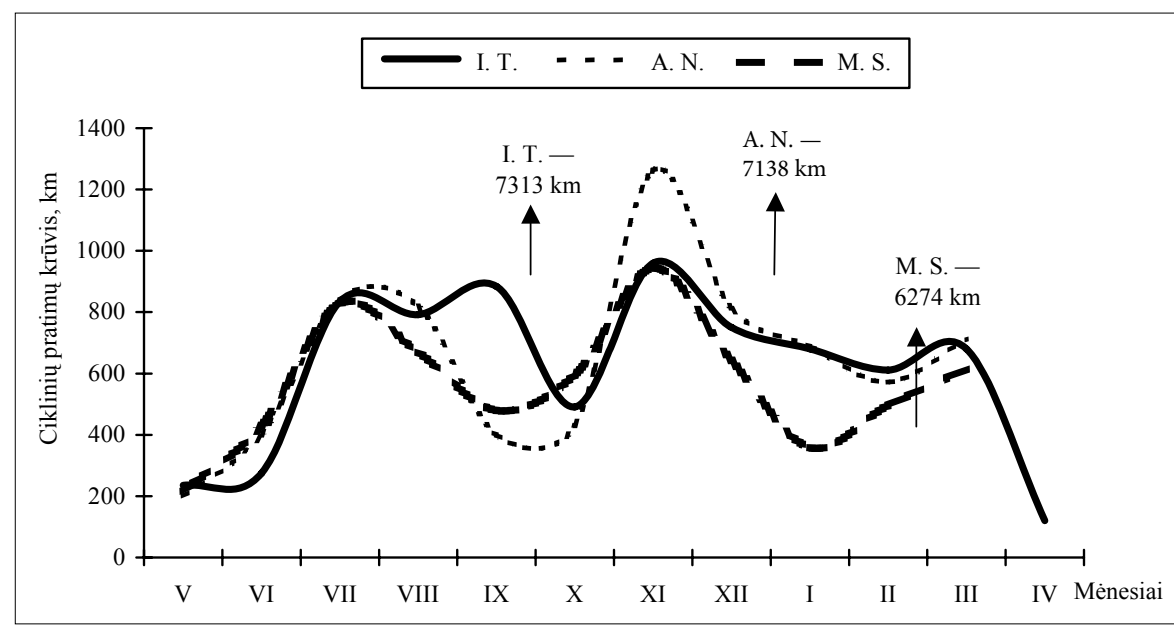

1 pav. Lietuvos olimpinès slidinèjimo rinktinès kandidatų ciklinių pratimų krūvio kaita per 2004 / 2005 metụ rengimo ciklą
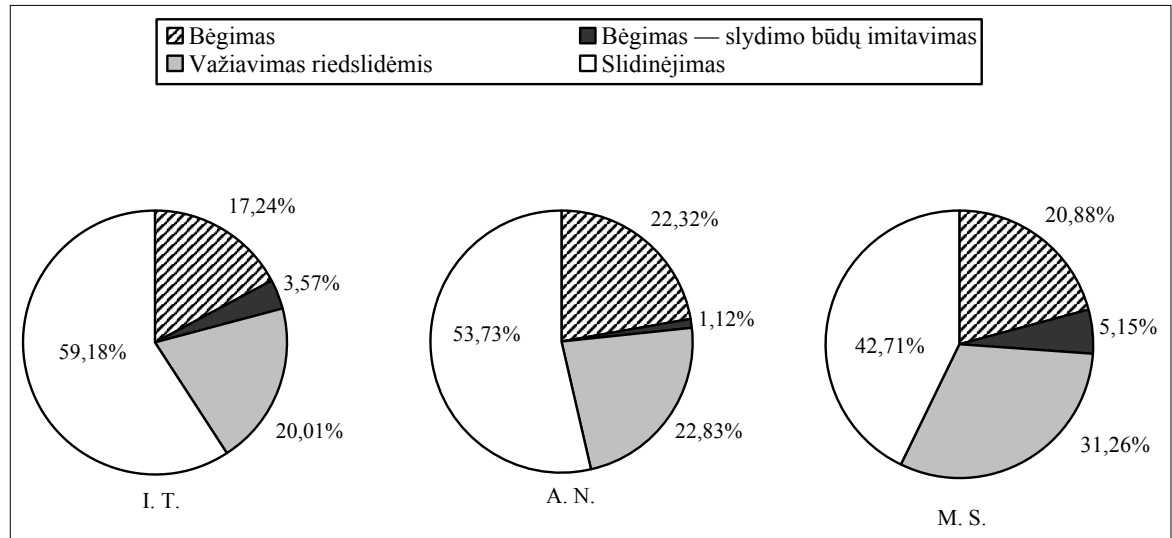

2 pav. Lietuvos olimpinès slidinëjimo rinktinès kandidatų ciklinių pratimų krūvio skirstinys (\%) pagal treniruotès priemones per 2004 / 2005 metų rengimo ciklą

Slidininkè I. T. ir slidininkas A. N. geriausius rezultatus pasiekè per pagrindines sezono varžybas: pasaulio žiemos universiadą (sausio mèn.), pasaulio slidinèjimo čempionatą (vasario mèn.). Abu slidininkai įvykdė olimpinį normatyvą, suteikiantị teisę dalyvauti olimpinèse žiemos žaidynèse. Olimpinis normatyvas - rezultatas, ivertintas ne daugiau kaip 100 FIS baudos tašku. Slidininkè I. T. per Pasaulio slidinèjimo taurès etapo varžybas $5 \mathrm{~km}$ lenktynèse laisvuoju stiliumi pasiekè rezultatą, ivertintą 59,78 taško. Slidininkas A. S. savo geriausius rezultatus pasiekè per Lietuvos čempionatą vasario mènesi, dalyvavo pasaulio jaunimo slidinejjimo čempionate kovo mènesi ir sprinto lenktynèse pasiekè rezultatą, ivertintą 143,59 FIS taško.

Slidininkų ciklinių pratimų (bėgimo, slydimo būdų imitavimo, važiavimo riedslidèmis ir slydimo slidèmis) krūvis per metų treniruotès ciklą siekè: I. T. $-7313,5 \mathrm{~km}$, A. N. $-7138 \mathrm{~km}$, M. S. $6274 \mathrm{~km}$ (1 pav.). Pagrindinę ciklinių pratimu krūvio dalį sudarè specifinis krūvis - slidinèjimas ir važiavimas riedslidèmis ( 2 pav.). Slidininkès I. T. slydimo slidèmis krūvis buvo $-4327,8 \mathrm{~km}$, slidininku A. N. $-3835 \mathrm{~km}$ ir M. S. $-2680 \mathrm{~km}$.
Slidininkų fizinio darbingumo rodiklių minant veloergometrą skirtingo intensyvumo zonose, širdies susitraukimų dažnio, plaučių ventiliacijos, deguonies suvartojimo ties aerobinio ir anaerobinio slenksčio ribomis, pasiekus kritinio intensyvumo ribą, rodiklių kaita per metini treniruotès ciklą pateikta 3, 4, 5 paveiksle.

Slidininkė I. T. ir slidininkas M. S. didžiausius $\mathrm{VO}_{2 \max }$, maksimalios plaučių ventiliacijos rodiklius ties kritinio intensyvumo riba pasiekè varžybu laikotarpio pradžioje ( $3 \mathrm{c}, 3 \mathrm{~d}, 5 \mathrm{c}, 5 \mathrm{~d}$ pav.), o slidininko A. N. šių rodiklių didžiausios reikšmès buvo užfiksuotos baigus varžybų laikotarpi balandžio mènesi ( $4 \mathrm{c}, 4 \mathrm{~d}$ pav.). Slidininkų didžiausiasis deguonies suvartojimas procentais, pasiekus anaerobinès apykaitos slenksti, varžybu laikotarpio pradžioje buvo: I. T. $-89,49 \%$, A. N. $-81,1 \%$, M. S. $-84,00 \% \mathrm{VO}_{2 \max }(6$ pav.). Slidininkès I. T. ir slidininko M. S. kojų raumenų vienkartinio susitraukimo santykinis galingumas baigus varžybų laikotarpi buvo prastesnis negu parengiamuoju laikotarpiu (rugsejjo mèn.), o slidininko A. N. priešingai — baigus varžybu laikotarpi šis rodiklis buvo aukštesnis nei rugsèjo mènesi (1 lent.). 
3 pav. Slidininkès I. T., minančios veloergometrą skirtingose energijos gamybos zonose, fizinio darbingumo (a), širdies susitraukimų dažnio (b), deguonies suvartojimo (c), plaučių ventiliacijos (d) kaita per 2004-2005 m. rengimo ciklą
4 pav. Slidininko A. N., minančio veloergometrą skirtingose energijos gamybos zonose, fizinio darbingumo (a), širdies susitraukimų dažnio (b), deguonies suvartojimo (c), plaučiụ ventiliacijos (d) kaita per 2004-2005 m. rengimo ciklą
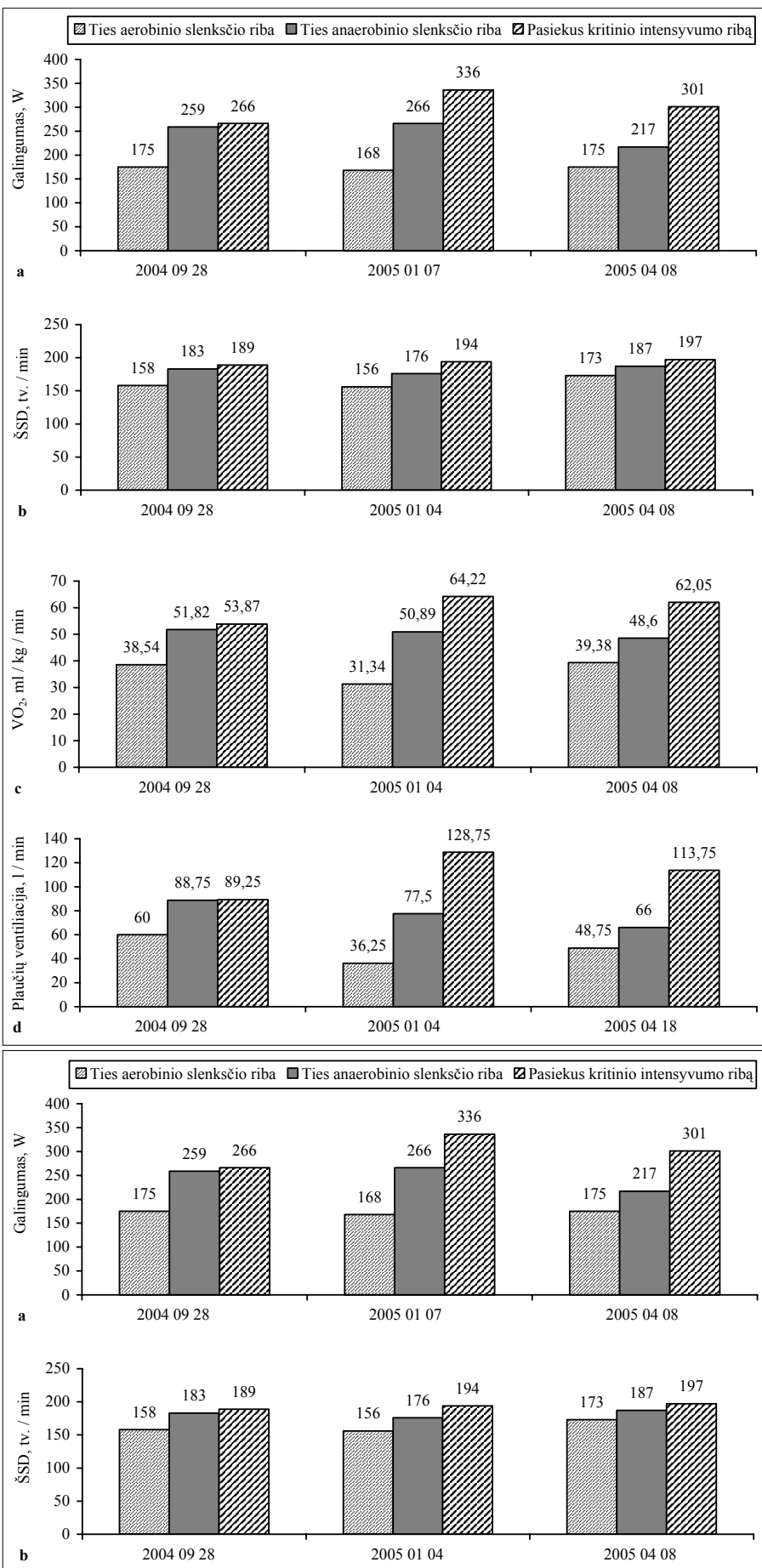

b

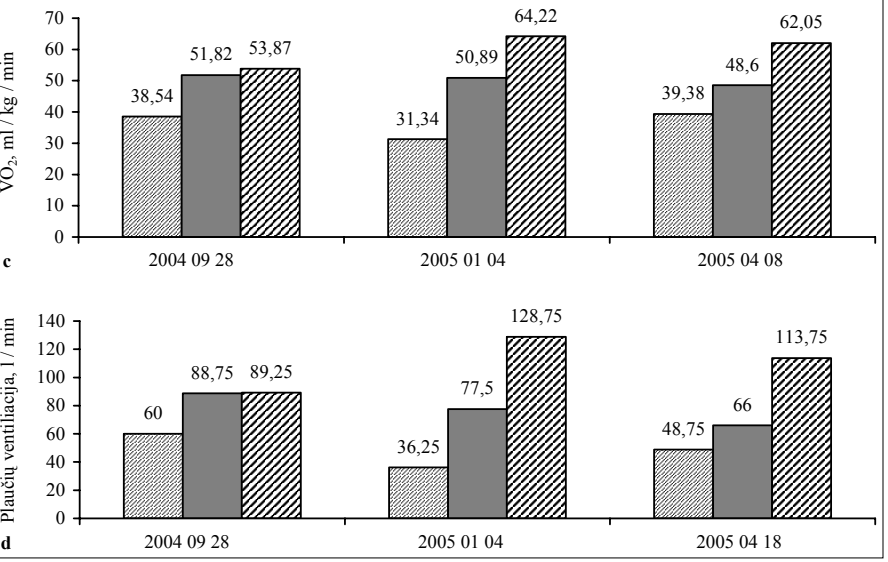



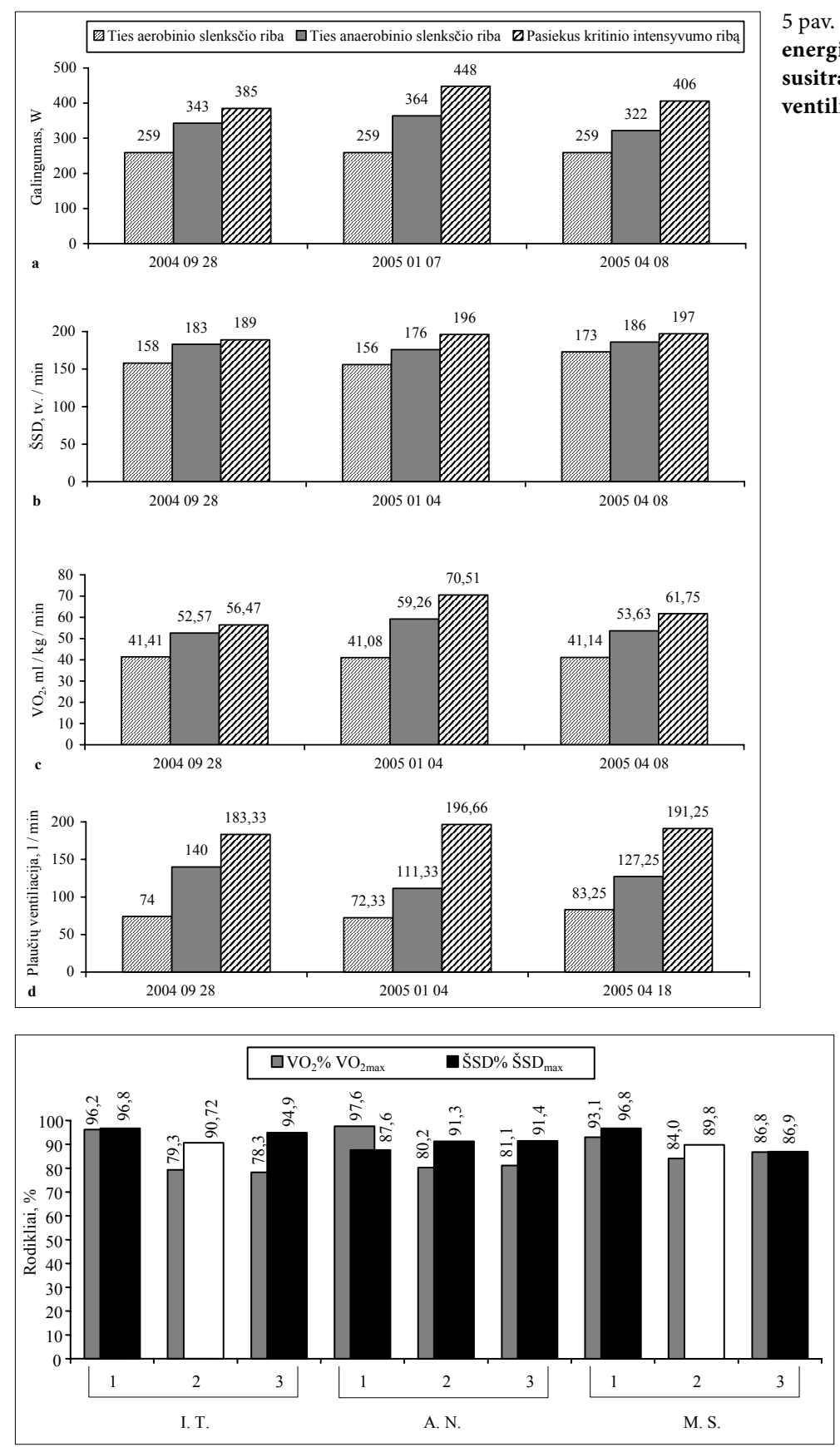

5 pav. Slidininko M. S., minančio veloergometrą skirtingose energijos gamybos zonose, fizinio darbingumo (a), širdies susitraukimų dažnio (b), deguonies suvartojimo (c), plaučių ventiliacijos (d) kaita per $2004-2005$ m. rengimo ciklą
6 pav. Lietuvos olimpinès slidinėjimo rinktinès kandidatų (minančių veloergometrą) deguonies suvartojimo procentais $\mathrm{VO}_{2 \max }$ ir širdies susitraukimų dažnio procentais $\breve{S S D}_{\max }$ pasiekus anaerobinio slenksčio ribą kaita per $2004-2005 \mathrm{~m}$. rengimo ciklą

Pastaba.

$1-20040928 ; 2-20050107 ; 3-20050408$
Slidininkų širdies susitraukimo dažnis atliekant anaerobini alaktatini-laktatinị darbą (30 šuolių aukštyn iš vietos maksimaliomis pastangomis) po krūvio balandžio mènesị buvo didesnis negu rugsèjo mènesi, bet širdies darbo atsigavimas buvo greitesnis (2 lent.). Laikotarpiu nuo rugsejjo iki balandžio mènesio pagerejjo slidininkès I. T. vestibulinès funkcijos rodikliai, o slidininko M. S. pailgejo pusiausvyros atgavimo trukmè (3 lent.). Balandžio mėnesi buvo padidèjęs visų slidininku emocinis labilumas, sumažèjo slidininko M. S. psichomotorinis tonusas ir agresyvumo laipsnis (4 lent.). Padidejo slidininkès I. T. ir slidininko A. N. nerimo laipsnis. Slidininkų psichoemocinès būsenos rodiklių kaita reiškèsi individualiais požymiais.

\section{REZULTATUQ APTARIMAS}

Slidininkų A. N. ir M. S. ciklinių pratimų krūvio apimtis per metų treniruotès ciklą buvo adekvati Lietuvos slidininkų olimpiečių R. Panavo ir V. Zybailos atliktai (Milašius, Čepulėnas, 2002), kai šie slidininkai rengèsi dalyvauti Solt Leik Sičio olimpinėse žiemos žaidynèse.

Slidininkès I. T. ciklinio darbo krūvio apimtis buvo didesnè už jos pačios atliktą krūvi per 2001-2002 metų treniruotès ciklą (Milašius, 
1 lentelè. Slidininkų kojų raumeny galingumo ir ištvermès rodiklių kaita per 2004 / 2005 metų rengimo ciklą

Pastaba.

I - 200409 28; II - 20050407.

2 lentelè. Slidininku organizmo adaptacijos prie anaerobinio krūvio (šuolių aukštyn per $30 \mathrm{~s}$ maksimaliomis pastangomis) rodikliu kaita per 2004 / 2005 metų rengimo ciklą

Pastaba.

I - 200409 28; II - 200504 07; ŠSD — širdies susitraukimų dažnis.

\begin{tabular}{|c|c|c|c|c|}
\hline \multirow{2}{*}{ Rodikliai } & \multirow{2}{*}{$\begin{array}{l}\text { Tyrimo etapai, skirtumas } \\
\text { (d) tarp rodiklių }\end{array}$} & \multicolumn{3}{|c|}{ Slidininkų inicialai } \\
\hline & & I. T. & A. N. & M. S. \\
\hline \multirow{3}{*}{ Šuolio aukštyn iš vietos aukštis, cm } & I & 34,5 & 41,6 & 52,4 \\
\hline & II & 35,5 & 39,9 & 53,0 \\
\hline & d & 1,0 & 1,7 & 0,6 \\
\hline \multirow{3}{*}{$\begin{array}{l}\text { Raumenų susitraukimo } \\
\text { galingumas, W / kg }\end{array}$} & I & 13,3 & 14,8 & 22,3 \\
\hline & II & 11,2 & 16,6 & 10,9 \\
\hline & $\mathrm{d}$ & 2,1 & 1,8 & 11,4 \\
\hline \multirow{3}{*}{ Greitumo rodiklis, $\%$} & I & 80,4 & 83,0 & 27,5 \\
\hline & II & 59,2 & 80,7 & 79,0 \\
\hline & $\mathrm{d}$ & 21,2 & 3,7 & 51,5 \\
\hline \multirow{3}{*}{ Jègos rodiklis, \% } & I & 87,3 & 83,9 & 84,7 \\
\hline & II & 82,6 & 81,0 & 84,0 \\
\hline & $\mathrm{d}$ & 4,7 & 2,9 & 0,7 \\
\hline \multirow{3}{*}{ Elastingumo rodiklis, \% } & I & 20,0 & 29,6 & 22,3 \\
\hline & II & 20,7 & 26,1 & 27,3 \\
\hline & $\mathrm{d}$ & 0,7 & 3,5 & 5,0 \\
\hline \multirow{3}{*}{$\begin{array}{l}\text { Vertikaliu šuolių aukštyn iš vietos } \\
\text { per } 30 \mathrm{~s} \text { aukščį suma, cm }\end{array}$} & I & 631,7 & 653,1 & 848,8 \\
\hline & II & 671,5 & 589,6 & 846,1 \\
\hline & $\mathrm{d}$ & 39,8 & 63,5 & 2,7 \\
\hline
\end{tabular}

\begin{tabular}{|c|c|c|c|c|}
\hline \multirow{2}{*}{ Rodikliai } & \multirow{2}{*}{$\begin{array}{l}\text { Tyrimo etapai, skirtumas } \\
\text { (d) tarp rodiklių }\end{array}$} & \multicolumn{3}{|c|}{ Slidininkų inicialai } \\
\hline & & I. T. & A. $N$. & M. S. \\
\hline \multirow{3}{*}{ ŠSD prieš krūvi, tv. / min } & I & 58 & 58 & 57 \\
\hline & II & 93 & 68 & 68 \\
\hline & d & 35 & 10 & 11 \\
\hline \multirow{3}{*}{ ŠSD po krūvio, tv. / min } & I & 138 & 138 & 147 \\
\hline & II & 151 & 158 & 157 \\
\hline & d & 13 & 20 & 10 \\
\hline \multirow{3}{*}{ ŠSD atsigavimas po krūvio per $2 \mathrm{~min}, \%$} & I & 71 & 66 & 87 \\
\hline & II & 98 & 82 & 102 \\
\hline & d & 27 & 16 & 15 \\
\hline \multirow{3}{*}{$\begin{array}{l}\text { Sistolinis kraujospūdis prieš krūvi } \\
\mathrm{mm} \mathrm{Hg}\end{array}$} & I & 120 & 110 & 125 \\
\hline & II & 115 & 125 & 140 \\
\hline & $\mathrm{d}$ & 5 & 15 & 15 \\
\hline \multirow{3}{*}{$\begin{array}{l}\text { Diastolinis kraujospūdis prieš krūvį } \\
\mathrm{mm} \mathrm{Hg}\end{array}$} & I & 75 & 70 & 75 \\
\hline & II & 75 & 70 & 85 \\
\hline & $\mathrm{d}$ & 0 & 0 & 10 \\
\hline \multirow{3}{*}{ Sistolinis kraujospūdis po krūvio, $\mathrm{mm} \mathrm{Hg}$} & I & 165 & 175 & 160 \\
\hline & II & 155 & 190 & 205 \\
\hline & d & 10 & 15 & 45 \\
\hline \multirow{3}{*}{$\begin{array}{l}\text { Diastolinis kraujospūdis po krūvio, } \\
\mathrm{mm} \mathrm{Hg}\end{array}$} & I & 15 & 30 & 5 \\
\hline & II & 0 & 25 & 10 \\
\hline & d & 15 & 5 & 5 \\
\hline \multirow{3}{*}{$\begin{array}{l}\text { Sistolinio kraujospūdžio atsigavimas po } \\
\text { krūvio per } 2 \mathrm{~min}, \mathrm{~mm} \mathrm{Hg}\end{array}$} & I & 135 & 135 & 145 \\
\hline & II & 130 & 82 & 160 \\
\hline & d & 5 & 53 & 15 \\
\hline \multirow{3}{*}{$\begin{array}{l}\text { Diastolinio kraujospūdžio atsigavimas po } \\
\text { krūvio per } 2 \mathrm{~min}, \mathrm{~mm} \mathrm{Hg}\end{array}$} & I & 68 & 55 & 60 \\
\hline & II & 70 & 35 & 80 \\
\hline & d & 2 & 20 & 20 \\
\hline
\end{tabular}




\begin{tabular}{|c|c|c|c|c|c|}
\hline & \multirow{2}{*}{ Rodikliai } & \multirow{2}{*}{ Tyrimo etapai } & \multicolumn{3}{|c|}{ Slidininkų inicialai } \\
\hline & & & I. T. & A. N. & M. S. \\
\hline \multirow{4}{*}{ Sukinys kairèn } & \multirow{2}{*}{ Pusiausvyros atgavimo trukmé, $\mathrm{s}$} & I & 17,0 & 19,0 & 7,0 \\
\hline & & II & 14,0 & 15,0 & 12,0 \\
\hline & \multirow{2}{*}{ Pasvirimo laipsnis } & I & 3,5 & 4,0 & 1,0 \\
\hline & & II & 2,0 & 2,0 & 1,5 \\
\hline \multirow{4}{*}{ Sukinys dešinėn } & \multirow{2}{*}{ Pusiausvyros atgavimo trukmè, $\mathrm{s}$} & I & 25,0 & 19,0 & 7,0 \\
\hline & & II & 12,0 & 22,0 & 12,0 \\
\hline & \multirow{2}{*}{ Pasvirimo laipsnis } & I & 5,0 & 5,0 & 1,0 \\
\hline & & II & 1,5 & 4,0 & 1,5 \\
\hline
\end{tabular}

3 lentelè. Slidininkų vestibulinès funkcijos įvertinimo rodiklių kaita per 2004 / 2005 m. rengimo ciklą

\begin{tabular}{|c|c|c|c|c|c|}
\hline \multirow{2}{*}{\multicolumn{2}{|c|}{ Rodikliai }} & \multirow{3}{*}{$\begin{array}{c}\text { Tyrimo etapai } \\
\text { I }\end{array}$} & \multicolumn{3}{|c|}{ Slidininkų inicialai } \\
\hline & & & \multirow{2}{*}{$\begin{array}{c}\text { I. T. } \\
56\end{array}$} & \multirow{2}{*}{$\begin{array}{c}\text { A. N. } \\
60\end{array}$} & \multirow{2}{*}{$\frac{\text { M. S. }}{-}$} \\
\hline \multirow{4}{*}{ Psichomotorinis tonusas } & \multirow{2}{*}{ Rodiklis } & & & & \\
\hline & & II & Norma & Padidintas & - \\
\hline & \multirow{2}{*}{ Vertinimas } & I & 70 & 49 & 31 \\
\hline & & II & Padidintas & Norma & Pamažintas \\
\hline \multirow{4}{*}{ Ekstrainvertiškumas } & \multirow{2}{*}{ Rodiklis } & I & 54 & 76 & - \\
\hline & & II & Norma & Ekstravertas & - \\
\hline & \multirow{2}{*}{ Vertinimas } & I & 38 & 28 & 43 \\
\hline & & II & Intravertas & Intravertas & Norma \\
\hline \multirow{4}{*}{ Agresyvumo laipsnis } & \multirow{2}{*}{ Rodiklis } & I & 39 & 39 & - \\
\hline & & II & Pamažintas & Pamažintas & - \\
\hline & \multirow{2}{*}{ Vertinimas } & I & 47 & 28 & 38 \\
\hline & & II & Norma & Pamažintas & Pamažintas \\
\hline \multirow{4}{*}{ Emocinis labilumas } & \multirow{2}{*}{ Rodiklis } & I & 51 & 53 & - \\
\hline & & II & Norma & Norma & - \\
\hline & \multirow{2}{*}{ Vertinimas } & I & 67 & 62 & 71 \\
\hline & & II & Padidintas & Padidintas & Padidintas \\
\hline \multirow{4}{*}{ Nerimo laipsnis } & \multirow{2}{*}{ Rodiklis } & I & 51 & 65 & - \\
\hline & & II & Norma & Padidintas & - \\
\hline & \multirow{2}{*}{ Vertinimas } & I & 83 & 65 & 52 \\
\hline & & II & Padidintas & Padidintas & Norma \\
\hline
\end{tabular}

4 lentelè. Slidininkų psichoemocinès būsenos ir ịvertinimo rodikliụ kaita per 2004 / 2005 m. rengimo ciklą

Čepulėnas, 2002), rengiantis dalyvauti Solt Leik Sičio olimpinèse žaidynèse. Siekiant didelio sportinio meistriškumo, svarbi ne tik atliekamo krūvio apimtis. Aktualu modeliuoti treniruotès fizinius krūvius pagal varžybinès veiklos sukeliamus organizmo funkcinių sistemų pokyčius (Gaskill et al., 1999; Баталов, 2000; Раменская, 2000; Millet et al., 2003; Rusko, 2003 a, 2003 b). Slidininkų specialiosios jègos lavinimo pratybos didina varžybinès veiklos darbo ekonomiškuma, atliekamo darbo galingumą ties anaerobinès apykaitos slenksčio riba (Hoff et al., 2002; Osteras et al., 2002). Slidininkų maksimaliojo deguonies suvartojimo rodiklius galima padidinti atliekant kartotinius didelio intensyvumo 30 minučių trukmès krūvius su atsigavimo pertraukomis (Biladeau et al., 1994).

Tirtų slidininkų A. N. ir M. S. $\mathrm{VO}_{2 \max }$ rodikliai daug mažesni nei elito slidininkų (Hottenrott, Urban, 1998; Rusko, 2003 a) ir dar nepasiekè ankstesnių Lietuvos slidininkų olimpiečių R. Panavo ir $\mathrm{V}$. Zybailos $\mathrm{VO}_{2 \max }$ rodiklių (Milašius ir kt., 1998; Milašius, Čepulènas, 2002) maksimalių reikšmių lygmens. Tirtų slidininkų $\mathrm{VO}_{2 \max }$ rodikliai nuo rugsèjo iki sausio ménesio akivaizdžiai pagerèjo (3, 4, 5 pav.). E. Mygind ir kt. (1991) atlikti tyrimai rodo, kad slidininku $\mathrm{VO}_{2 \max }$ rodikliai rugsèjo ménesi siekia $89,4 \%$ šiu rodiklių maksimaliujų individualių dydžiu ir iki gruodžio smarkiai $(\mathrm{p}<0,05)$ padidejja, o balandi būna 2,3\% mažesni nei gruodị.

Šiuolaikinès slidinėjimo lenktynès labai suaktyvina energijos gamybą anaerobinemis glikolitinèmis reakcijomis. Per $15 \mathrm{~km}$ slidinèjimo lenktynių varžybas didelio meistriškumo slidininkų kraujyje laktato koncentracija siekia $(\bar{\chi}+\mathrm{SD})-$ 
$13,9 \pm 1,8 \mathrm{mmol} / 1$, o slidininkių — per $10 \mathrm{~km}$ lenktynes padidèja iki 12,4 $\pm 1,6 \mathrm{mmol} / \mathrm{l}$ (Rusko et al., 2003 b).

Mūsų tiriamų slidininkų anaerobinès glikolitinès energijos gamybos reakcijos pasiekus kritinio intensyvumo ribą (minant veloergometrą) suaktyvejja nedaug. Atlikus fizinį krūvị, slidininku I. T., A. N., M. S. laktato koncentracija kraujyje siekè atitinkamai: sausio mènesi $-5,2 \mathrm{mmol} / 1$, $5,06 \mathrm{mmol} / 1,3,67 \mathrm{mmol} / 1$, o balandi $5,88 \mathrm{mmol} / 1 ; 6,01 \mathrm{mmol} / 1,5,88 \mathrm{mmol} / 1$.

Slidininkų treniruotès pratybos važiuojant riedslidėmis anaerobinès apykaitos slenksčio intensyvumu didina slidininkų specifinio darbo ekonomiškumą (Mahood et al., 2001). Slidininku I. T., A. N., M. S. važiavimo riedslidėmis krūvis (2 pav.) sudare atitinkamai 20,01, 22,83, 31,25\% viso ciklinių pratimų krūvio, atlikto per metų treniruotès ciklą. Didelio meistriškumo 20 ir 22 metu slidininkai per metų treniruotès ciklą riedslidėmis ịveikia 1450 ir $1344 \mathrm{~km}$ (Rusko, 2003 b), ir šis krūvis sudaro 17,68-17,74\% viso ciklinių pratimų krūvio. Slidininkų I. T., A. N., M. S. atliekamo darbo energinè vertè minant veloergometrą ties kritinio intensyvumo riba varžybų laikotarpio pradžioje (sausio mèn.) siekè atitinkamai 10,92, 11,23, 12,28 $\mathrm{ml} \mathrm{O}_{2} / 1 \mathrm{~W}$.

Slidininkų jègos pratybų krūviai padidina darbo galingumą ties anaerobinio slenksčio riba (Hoff et al., 1999). Slidininkams rekomenduotini ir intensyvūs 20 bei $180 \mathrm{~s}$ krūviai, atliekami intervaliniu metodu (Nilsson et al., 2004). Šiuolaikinèje slidininkų lenktynininkų treniruotèje didelis dèmesys skiriamas jègai ir specialiajai jègai lavinti (Komi, Norman, 1987; Paavolainen et al., 1991; Hottenrott, Urban, 1998; Hoff et al., 2002; Osteras et al., 2002).

Lietuvos slidininkų treniruotès krūvių analizè leidžia teigti, kad jègos lavinimui skiriama per mažai dèmesio, o pratybose mažai taikomi intervalinis ir kartojimo metodai. Didelio meistriškumo slidininkų rengimui būtinos pratybos aukštikalnèse (Ingjer, Myhre, 1992). Pratybos aukštikalnèse ( $2500 \mathrm{~m}$ virš jūros lygio ir aukščiau) skatina organizmą gaminti eritropoetiną, dèl kurio aktyvejja raudonujų kraujo kūneliu gamyba, padaugeja eritrocitu ir padideja kraujo galimybès pernešti daugiau deguonies i raumenis (Rusko et al., 1999; Schena et al., 2002; Wilber, 2004).

Lietuvos olimpinès slidinejjimo rinktinès kandidatų maksimaliojo deguonies suvartojimo rodikliai $(3,4,5$ pav.) daug mažesni nei pa- saulio elito slidininku (Rusko, 2003 a). Norint gerinti maksimaluji deguonies suvartojima, reiketu daugiau ir tikslingiau taikyti pratybas aukštikalnèse, taip pat dirbtinès hipoksijos sąlygas (Rusko et al., 1999; Wilber, 2004) - gyvenama ir ilsimasi specialiuose nameliuose, kuriuose dirbtinai sudaromos aukštikalnių sąlygos, o treniruojamasi iprastomis lygumų sąlygomis arba mažo aukščio kalnuose.

Tobulinant tiriamų slidininkų sportini parengtumą, reikètú didinti darbo galingumą ties anaerobinio slenksčio, kritinio intensyvumo riba ir maksimaluji deguonies suvartojimą.

\section{IŠVADOS}

1. Lietuvos slidininku — olimpinès rinktinès kandidatu — deguonies suvartojimo ir širdies susitraukimų dažnio reikšmès ties anaerobinio slenksčio riba artimos šių rodiklių reikšmėms, pasiekus kritinio intensyvumo ribą, ir tai rodo dideli jų aerobinių galių talpumo lygi. Deguonies suvartojimo rodikliai ties anaerobinio slenksčio riba procentais $\mathrm{VO}_{2 \max }$ atitinka didelio meistriškumo ištvermès šaku sportininkų modelinius rodiklius.

2. Slidininkų maksimaliojo deguonies suvartojimo rodikliai mažesni negu didelio meistriškumo slidininkų modeliniai rodikliai. Tikslinga per treniravimo vyksmą taikyti daugiau treniruotes priemonių ir fizinių krūvių, skatinančių maksimaliojo deguonies suvartojimo didèjimą. Slidininkès I. T. ir slidininko M. S. geriausi fizinio darbingumo ir funkciniu galių rodikliai buvo varžybų laikotarpio pradžioje, o slidininko A. N. - varžybų laikotarpio pabaigoje.

3. Slidininkès I. T. ir slidininko M. S. kojų raumenų vienkartinio susitraukimo santykiniai galingumo rodikliai sezono pabaigoje buvo prastesni negu parengiamuoju treniruotes laikotarpiu (rugsèjo mèn.), o slidininko A. N. — priešingai: pabaigoje buvo geresni negu rugsėjo mènesi.

4. Slidininkų vestibulinès funkcijos ir psichoemocinès būsenos rodiklių kaita metiniu treniruotès ciklu reiškiasi individualiais požymiais, $\mathfrak{i}$ kuriuos reikia atsižvelgti organizuojant treniravimo vyksmą. 


\section{LITERATŪRA}

Biladeau, B., Roy, B., Baulay, M. R. (1994). Effect of drafting on heart rate in cross-country skiing. Journal of Medicine Science Sports and Exercises, Vol. 26 (5), $637-641$.

Bompa, T. O. (1999). Periodization: Theory and Methodology of Training. United States: Human Kinetics.

Bosco, C. (1999). Strength Assessment with the Bosco's Test. Rome: Italian Society of Sport Science.

Čepulènas, A. (2001). Slidininku rengimo technologija: monografija. Kaunas: Lietuvos kūno kultūros akademija.

Eisenman, P. A., Johnson, S. C., Bainbridge, C. N., Zupan, M. F. (1989). Applied physiology of cross-country skiing. Journal of Sports Medicine, 8 (2), 67-79.

Gaskill, S. E., Serfass, R. C., Bacharach, D. W., Kelly, J. M. (1999). Responses to trainingi in cross-country skiers. Journal of Medicine Science Sports and Exercises, 31 (8), $1211-1217$.

Hoff, J., Gran, A., Helgerud, J. (2002). Maximal strength training improves aerobic endurance performance. Scandinavian Journal of Medicine Science Sports, 12 (5), 288-295.

Hoff, J., Helgerud, J., Wisloff, U. (1999). Maximal strength training improves work economy in trained female cross-country skiers. Journal of Medicine Science Sports and Exercises, 31, 870-877.

Hottenrott, K., Urban, V. (1998). Handbuch für Skilanglauf. Aachen: Meyer und Meyer.

Ingjer, F., Myhre, K. (1992). Physiological effects of altitude training on elite male cross-country skiers. Journal of Sports Science, 10 (1), 37-47.

Jasiūnas, V., Vainoras, A., Poderys, J., Jasiūnienè, N. (1997). Kauno sportininkų testavimo ir reabilitacijos centro teikiamos paslaugos. Treneris, 2, 18-21.

Komi, P. V., Norman, R. W. (1987). Preloading of the trust phase in cross-country skiing. International Journal of Sports Medicine, 8, Suppl. 1, 48-54.

Lietuvos sportininku rengimo ir dalyvavimo $X X$ žiemos olimpinèse žaidynèse programa , Turinas 2006“. (2003). Rengè A. Raslanas, V. Gudiškis, K. Steponavičius, V. Vencienè, J. Skernevičius. Vilnius: Lietuvos tautinis olimpinis komitetas, Kūno kultūros ir sporto departamentas.

Mahood, N. V., Kenefick, R. W., Kertzer, R., Quinn, T. J. (2001). Physiological determinants of cross-country ski racing performance. Journal of Medicine Science Sports and Exercises, 33 (8), 1379-1384.

Milašius, K. (1997). Ištverme lavinančiu sportininku organizmo adaptacija prie fiziniu krūviu: monografija. Vilnius: Vilniaus pedagoginis universitetas.

Milašius, K., Čepulènas, A. (2002). Lietuvos žiemos šaku sportininkų rengimo XIX žiemos olimpinėms žaidynėms Solt Leik Sityje strategija, technologija, mokslinis valdymas, rezultatai. Ugdymas. Küno kultūra. Sportas, 4 (45), 62-75.

Milašius, K. Skernevičius, J., Damskis, S., Karoblis, P., Slavuckienè, R. (1998). Lietuvos slidininkų, XVIII Nagano olimpinių žiemos žaidynių dalyvių, organizmo adaptacijos prie fizinių krūvių per keturmeti pasirengimo ciklą analizè. Sporto mokslas, 5 (14), 57-60.

Millet, G. P., Boissiere, D., Candau, R. (2003). Energy cost of different skating techniques in cross-country skiing. Sports Science, 21 (1), 3-11.
Mygind, E., Larsson, B., Klausen, T. (1991). Evaluation of specific test in cross-country skiing. Journal of Sports Science, 9 (3), 249-257.

Nilsson, J. E., Holmberg, H. C., Tveit, P., Hallen, J. (2004). Effects of 20-s and 180-s double poling interval training in cross-country skiers. European Journal of Applied Physiology, 92 (1-2), 121-127.

Osteras, H., Helgerus, J., Hoff, J. (2002). Maximal strength-training effects on force-velocity and force-power relationships explain increases in aerobic performance in humans. European Journal of Applied Physiology, 88 (3), 255-263.

Paavolainen, L., Hakkinen, K., Rusko, H. (1991). Effects of explosive type strength training on physical performance characteristics in cross-country skiers. European Journal of Applied Physiology, 62 (4), 251-255.

Raslanas, A. (2001). Lietuvos didelio meistriškumo sportininku rengimo sistema: habilitacinis darbas. Vilnius: VPU.

Rusko, H. K., Tiikaen, H., Paavolainen, L. et al. (1999). Effect of living in hypoxia and training in normoxia on sea level $\mathrm{VO}_{2 \max }$ and red cell mass. Journal of Medicine Science Sports and Exercises, 31 (5), 86.

Rusko, H. (2003 a). Physiology of Cross Country Skiing. Handbook of Sports Medicine and Science Cross Country Skiing. Edited by H. Rusko (pp. 7-31). Blackwell, Science.

Rusko, H. (2003 b). Training for Cross Country Skiing. Handbook of Sports Medicine and Science Cross Country Skiing. Edited by H. Rusko (pp. 62-100). Blackwell Science.

Schena, F., Cuzzolin, L., Rossi, L. et al. (2002). Plasma nitrite / nitrate and erythropoietin levels in cross-country skiers during altitude training. Journal of Sports Medicine and Physical Fitness, 42 (2), 129-134.

Welde, B., Evertsen, F., Von Heimburg, E., Ingulf Medbo, J. (2003). Energy cost of free technique and classical crosscountry skiing at racing speeds. Journal of Medicine Science Sports and Exercises, 35 (5), 818-825.

Wilber, R. L. (2004). Altitude Training and Athletic Performance. Human Kinetics.

Баталов, А. Г. (2000). Модельно-целевой способ построения спортивной подготовки высококвалифицированных спортсменов в зимних циклических видах спорта. Теория и практика физической культуры, 1, 46-52.

Верхошанский, Ю. В. (2005). Теория и методология спортивной подготовки: блоковая система тренировки спортсменов высокого класса. Теория и практика физической культуры, 4, 2-14.

Платонов, В. И. (1997). Общзая теория подготовки спортсменов в олимпийском спорте. Киев: Олимпийская литература.

Раменская, Т. И. (2000). Биоэнергетическое моделирование соревновательной деятельности сильнейших лыжников-гонщиков на XVIII зимних олимпийских играх (Нагано, 1998). Теория и практика физической культурьл, 2, 6-12. 


\title{
PHYSICAL LOADS APPLIED TO THE CANDIDATES FOR LITHUANIAN OLYMPIC SKIING TEAM, THE FLUCTUATION OF PHYSICAL EFFICIENCY, FUNCTIONAL POWER AND PSYCHOEMOTIONAL STATE DURING THE THIRD OLYMPIC CYCLE YEAR
}

\author{
Algirdas Čepulėnas, Arvydas Stasiulis, Jonas Poderys \\ Lithuanian Academy of Physical Education, Kaunas, Lithuania
}

\begin{abstract}
The perfection of skiers-racers' sports mastership and the development of sports results are possible along with steady improvement of the organism's functional systems. Steady improvement of the organism's functional systems is achieved while organizing the sports training process. The singleness of training process and its management in respect of individual properties of skiers' organisms' adaptation to physical loads are very important factors, influencing the effectiveness of sports preparation.

The objective of the paper - to analyze the physical loads applied to the candidates for the Lithuanian Olympic skiing team, to estimate the peculiarities of physical efficiency, functional power and the fluctuation of psychoemotional state during the third Olympic cycle year.

The object - loads of physical preparation, the rates and fluctuations of physical efficiency, capacity of leg muscles, gas turnover, respiratory frequency, cardiac systole frequency, psychoemotional state and molecular function of three skiers - I. T. (female), A. N. (male) and M. S. (male). The skiers are the candidates for the Lithuanian Olympic skiing team for participation in Olympic Winter Games of Turin 2006.

Research methods - the studies of research projects, the analysis of sportsmen's daybooks and competition documents, examination. The rates of the skiers' physical efficiency, gas turnover, respiratory and cardiac systole frequency have been determined at the Lithuanian Academy of Physical Education (the Laboratory of Motorics). Constantly increasing continuous physical loads have been applied to all skiers by using a veloergometer. The wheel frequency was 70 times / min (rotations). The sports gas analyzer "Oxycon Mobile" has been used during the physical performance to continuously register pulmonary ventilation, respiratory frequency, oxygen usage $\left(\mathrm{VO}_{2}\right)$, oxygen pulse, the capacity of performance $(\mathrm{W})$ and cardiac systole frequency. The recording of cardiac systole frequency has been carried out using the "Polar AccuRec-Plus" pulse meter.

The systole capacity and stamina of the skiers' leg muscles, vestibular functions and the rate of psychoemotional state have been estimated in the Laboratory of Kinesiology.

The loads of cycle exercises (running, imitation of sliding move, rollerskiing, skiing) performed by the skiers during one year training cycle were $7313.5 \mathrm{~km}$ (I. T. - female), $7150 \mathrm{~km}$ (A. N. - male) and $6279 \mathrm{~km}$ (M. S. - male). At the beginning of the competition the rates of functional capacity of the skiers I. T. (female) and M.S. (male) were the highest, meanwhile, the highest rate of functional capacity of the skier A. N. (male) was at the end of the competition.

The Lithuanian Olympic skiing team candidates' $\mathrm{VO}_{2}$ and cardiac systole frequency values beside the anaerobic threshold were similar to values of those rates, after reaching the limit of critical intensity $\left(\mathrm{VO}_{2 \text { max }}\right)$. It indicates the high level aerobic power capacity of the skiers. The percentage of $\mathrm{VO}_{2}$ consumption and $\mathrm{VO}_{2 \max }$ rates beside anaerobic threshold limits comply with the regulation requirements of stamina for high mastership sportsmen. The rates of the sportsmen's maximum oxygen consumption $\left(\mathrm{VO}_{2 \max }\right)$ are lower in comparison to ones of elite skiers. During the training process, it is reasonable to apply more physical loads, which stimulate $\left(\mathrm{VO}_{2 \max }\right)$ the increase of oxygen consumption rates.

The skiers' vestibular function rates were better at the end of competition in comparison to those at the preparation period. The fluctuation of the skiers' psychoemotional state rate is common to individual fluctuation features.

Keywords: Olympic cycle, physical load, physical efficiency, functional capacity, anaerobic threshold, cardiac systole frequency. Algirdas Čepulènas Lietuvos kūno kultūros akademija (Lithuanian Academy of Physical Education)

